\title{
The Feeding Value of Extruded Corn Grain in a Corn Silage-Based Ration for High-Producing Holstein Cows and Heifers During Mid Lactation
}

\author{
P. Rezamand, S. M. Andrew, ${ }^{1}$ and T. A. Hoagland \\ Department of Animal Science, University of Connecticut, Storrs 06269-4040
}

\begin{abstract}
The objective of this study was to investigate the feeding value of extruded corn in a corn silage-based ration for high-producing Holstein cows during mid lactation. Sixteen multiparous and 8 primiparous Holstein cows $(106 \pm 49.7 \mathrm{~d}$ in milk; $43.7 \pm 5.27 \mathrm{~kg}$ of milk/d) were paired based on parity, days in milk, milk production, and body condition score and assigned to 1 of 2 dietary treatments in a randomized block design for 10 wk including a 2-wk adaptation period. Cows were fed a total mixed ration and milked 3 times per day. Diets contained $44 \%$ forage (3:1; corn silage:grass silage), $44.7 \%$ grain, and either extruded corn (EXC) or finely ground corn (FGC) at $11.3 \%$ of ration dry matter. No significant differences were detected in dry matter intake, milk protein yields, fat-corrected milk yields, or body condition score between cows fed FGC and cows fed EXC. Multiparous cows fed EXC produced more milk during wk 3 through 8 with a reduced milk fat content compared with multiparous cows fed FGC. Milk protein content was greater for primiparous cows fed EXC during wk 5 through 8 compared with primiparous cows fed the FGC ration. The major effect of feeding $2.7 \mathrm{~kg} / \mathrm{d}$ of EXC compared with FGC was an increase in milk production and a reduction in milk fat content for multiparous cows, and an increase in milk protein content for primiparous cows.
\end{abstract}

Key words: extruded corn, milk production, mid-lactation Holstein cow

\section{INTRODUCTION}

Corn grain is the major source of starch in dairy cattle rations in the United States (Chen et al., 1994; Theurer et al., 1999). The degree of availability of starch to rumen microbes affects the efficiency of rumen fermentation and productivity of lactating cows, and is influ-

Received July 7, 2006.

Accepted March 1, 2007

${ }^{1}$ Corresponding author: sheila.andrew@uconn.edu enced by ration composition, type of grain, and processing method (Owens et al., 1986; Theurer, 1986). Processing grains by pelleting and steam flaking increases ruminal and total tract starch digestibilities. Exposure to heat, moisture, and pressure causes starch gelatinization and denaturation of proteins surrounding starch granules and results in greater microbial access to the starch in grain (Kotarski et al., 1992; Knowlton et al., 1998; Ryu et al., 1999). An increase in total tract digestibility of starch and postruminal digestibility of NSC for cows fed highly processed corn has also been reported (Knowlton et al., 1996; Shabi et al., 1999). However, excessive ruminal starch digestion can lead to rumen acidosis (Goff, 2006).

Several studies have shown that milk and milk protein yields were improved and milk fat content was decreased with an increased degree of corn processing (Theurer et al., 1999; Dhiman et al., 2002). Greater ruminal starch digestion is associated with increased rumen microbial protein production (Theurer et al., 1999; Remond et al., 2004). Crocker et al. (1998) reported an increase in $\mathrm{N}$ flow to the duodenum as the degree of starch processing increased, which was thought to be the result of increased microbial protein and undegraded grain protein flow to the abomasum (Zinn, 1990; Dann et al., 1999). Dhiman et al. (2002) reported a decrease in milk fat content for cows fed finely ground corn compared with that of cows fed coarsely ground corn.

The extrusion method for processing corn has been used to improve digestibility of grains and starch gelatinization in livestock feeds, but has not been widely used in dairy rations (Ryu et al., 1999). Extrusion differs from other processing methods in that grain is exposed to steam, high temperature, and significant changes in pressure causing expansion of the processed grain (Castells et al., 2005). In one experiment, Shabi et al. (1999) reported a decrease in milk yield for dairy cows fed extruded corn with an improved efficiency of milk protein synthesis compared with cows fed ground corn. These effects were associated with decreased plasma urea $\mathrm{N}$ and ruminal ammonia $\mathrm{N}$ for cows fed extruded 
corn (Shabi et al., 1999). However, the sample size of the study conducted by Shabi et al. (1999) was limited $(\mathrm{n}=4)$ and focused on ruminal and postruminal digestibility of starch.

There is limited information on the effect of extrusion of the corn grain on performance of dairy cows. Therefore, the objective of the present study was to investigate the feeding value of extruded corn in a corn silagebased ration for high-producing Holstein cows during mid lactation.

\section{MATERIALS AND METHODS}

\section{Animals and Dietary Treatments}

Sixteen multiparous and 8 primiparous Holstein dairy cows from the University of Connecticut dairy herd were enrolled in the 12 -wk study. Cows were paired at mid lactation by DIM (106 \pm 49.7$)$, parity (median of 2 ; ranging from 1 to 4 ), and milk yield (43.7 \pm $5.27 \mathrm{~kg} / \mathrm{d}$ ), and were assigned to 1 of 2 dietary treatment groups. The trial consisted of a 2 -wk adaptation period to the feeding method (Calan gate feeding system; American Calan, Northwood, NH), a 2-wk adaptation period to new rations by slowly increasing the amount of processed corn in rations, and an 8-wk data collection period. The use of animals and all procedures of the study were approved by the Animal Care and Use Committee at the University of Connecticut.

\section{Feeding and Management}

Cows were housed in a 1-row freestall facility at the Kellogg Dairy Center at the University of Connecticut and fed individually using Calan feeding gates. Cows had free access to drinking water at all times and were fed a TMR consisting of corn silage, grass silage, alfalfa hay, concentrates, and one of the processed corn grains [either extruded corn (EXC) or finely ground corn (FGC) fed at $11.3 \%$ of DM; Table 1]. Cows were fed twice daily at approximately 0930 and $1630 \mathrm{~h}$. Rations were developed to meet nutrient requirements as recommended by the NRC (1989), and were fed to achieve 5 to $10 \%$ daily orts. Cows were milked 3 times daily at 0530, 1330, and $2130 \mathrm{~h}$, and daily milk yields were recorded electronically.

The finely ground corn used in this study had a mean particle size of $0.7 \mathrm{~mm}$ and a density of $0.58 \mathrm{~kg} / \mathrm{L}$. The extruded corn was produced from finely ground corn that was heated to approximately $121^{\circ} \mathrm{C}$ in the conditioning chamber on the extruder and held for $20 \mathrm{~min}$ at that temperature. The conditioned feed then entered the barrel of the extruder (single screw) and additional steam and pressure were applied. The extruded corn was dried to approximately $91 \% \mathrm{DM}$ and the final den-
Table 1. Ingredient and nutrient composition of the 2 experimental rations, 1 containing finely ground corn (FGC), and 1 containing extruded corn (EXC) fed for an 8-wk period to multiparous and primiparous Holstein cows

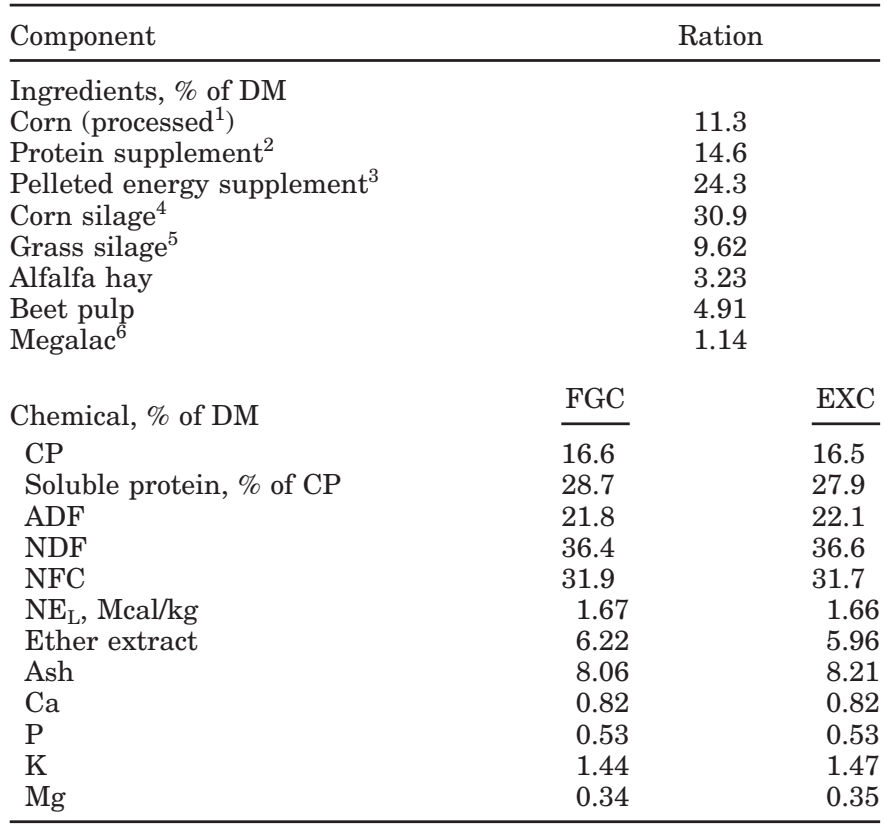

${ }^{1}$ Processed as FGC or EXC.

${ }^{2}$ Protein supplement contained $\mathrm{CP}, \mathrm{ADF}, \mathrm{NDF}, \mathrm{Ca}, \mathrm{P}$, and $\mathrm{NE}_{\mathrm{L}}$ of $44.0,5.90,12.2,1.87,0.86 \%$, and $1.98 \mathrm{Mcal} / \mathrm{kg}$ of DM, respectively.

${ }^{3}$ Pelleted energy supplement contained $\mathrm{CP}, \mathrm{ADF}, \mathrm{NDF}, \mathrm{Ca}, \mathrm{P}$, and $\mathrm{NE}_{\mathrm{L}}$ of $21.1,13.1,30.4,1.77,0.66 \%$, and $1.82 \mathrm{Mcal} / \mathrm{kg}$ of DM, respectively.

${ }^{4}$ Corn silage contained DM, CP, available protein (\% CP), soluble protein $(\% \mathrm{CP})$, degradable protein (\% CP), ADF, NDF, NSC, starch, ether extract, ash, $\mathrm{Ca}, \mathrm{P}$, and $\mathrm{NE}_{\mathrm{L}}$ of $30.4,8.47,7.77,57.3,74.3,28.8$, $46.9,31.1,28.6,3.43,5.84,0.28,0.29 \%$ and $1.54 \mathrm{Mcal} / \mathrm{kg}$ of DM, respectively.

${ }^{5}$ Grass silage contained DM, CP, available protein (\% CP), soluble protein (\% CP), degradable protein (\% CP), ADF, NDF, NSC, starch, ether extract, ash, $\mathrm{Ca}, \mathrm{P}$, and $\mathrm{NE}_{\mathrm{L}}$ of $19.3,14.3,13.0,49.7,63.0,39.0$, $57.7,7.87,2.40,5.13,11.6,0.60,0.42 \%$ and $1.23 \mathrm{Mcal} / \mathrm{kg}$ of DM, respectively.

${ }^{6}$ Church and Dwight Co. Inc., Princeton, NJ.

sity was $0.54 \mathrm{~kg} / \mathrm{L}$. The extruded corn was not further processed and was mixed with the TMR.

\section{Milk and Feed Sampling and Analyses}

The treatment rations offered and orts from individual cows were recorded and sampled daily at approximately 0930 h. Dry matter was determined on weekly composite samples of treatment rations and orts by drying in a forced air oven for $48 \mathrm{~h}$ at $65^{\circ} \mathrm{C}$. Weekly feed and orts samples were composited monthly by treatment and analyzed for CP (Kjeldahl, $\mathrm{N} \times 6.25$ ), soluble protein (Roe and Sniffen, 1990), ADF and NDF (Ankom A200 Filter Bag Technique, Ankom Technology, Fairport, NY), and starch (glucoamylase hydroly- 
sis, YSI 2700 Select Biochemistry Analyzer, YSI Incorporated, Yellow Springs, OH). Ether extract, ash, Ca, $\mathrm{P}, \mathrm{Mg}$, and $\mathrm{K}$ were analyzed by wet chemistry methods (Dairy One, Ithaca, NY). In addition, $\mathrm{NE}_{\mathrm{L}}$ (Van Soest and Fox, 1992) and NFC were calculated. Dry matter contents of corn silage and grass silage were determined weekly, and rations were adjusted based on changes in DM content of corn silage and grass silage when necessary.

Three consecutive milk samples were collected weekly for each individual cow, composited, and analyzed for fat, protein, lactose (by infrared spectroscopy), MUN, and SCC (by Fossomatic analysis; Dairy One). Mean milk protein yield $(\mathrm{kg} / \mathrm{d})$ and fat yield $(\mathrm{kg} / \mathrm{d})$ were calculated as weighted means. Somatic cell counts were log transformed for statistical analysis.

\section{$B W$ and $B C S$}

Body weights were measured weekly at approximately $1600 \mathrm{~h}$ using an electronic scale. Two trained individuals independently measured BCS each week at the same time as BW during the study period (Wildman et al., 1982). Body condition score was recorded to the nearest quarter point.

\section{Statistical Analysis}

Data were analyzed as a repeated-measure ANOVA using the MIXED procedure (SAS Institute, 1999) with week as the repeated variable. The model included treatment effect, parity, week, and 2- and 3-way interactions as fixed effects and cows within treatment as random effects. Milk yield and milk protein percentage were covariately adjusted by using the wk-1 pretrial milk yield and milk protein percentage averages, respectively. Protected least significance difference was used to compare least squares means. Significant differences between treatment groups were declared at $P$ $<0.05$.

\section{RESULTS AND DISCUSSION}

One primiparous cow was removed from the experiment due to clinical mastitis. Therefore, all means and comparisons are reported based on $\mathrm{n}=12$ for cows fed the EXC ration and $\mathrm{n}=11$ for cows fed the FGC ration. The ingredients and nutrient compositions of treatment rations are shown in Table 1. Starch and soluble protein contents of the extruded corn were 12.1 and $10.7 \%$ less than that of the finely ground corn, respectively (Table 2). However, although starch content was not measured in the TMR, it would be expected that ration starch would differ by less than $1.4 \%$ because all other ingredients were similar.
Table 2. Nutrient composition (as a percentage of DM) of the finely ground (FGC) and extruded (EXC) corn grain

\begin{tabular}{lcc}
\hline & \multicolumn{2}{c}{ Ration } \\
\cline { 2 - 3 } Component & FGC & EXC \\
\hline $\mathrm{NE}_{\mathrm{L}}, \mathrm{Mcal} / \mathrm{kg}$ & 2.18 & 2.07 \\
$\mathrm{CP}$ & 12.4 & 11.4 \\
Available protein & 11.9 & 10.6 \\
Soluble protein, \% of CP & 16.0 & 9.00 \\
ADF & 2.20 & 4.70 \\
$\mathrm{NDF}$ & 7.50 & 9.50 \\
Starch & 65.0 & 57.1 \\
Ether extract & 6.70 & 4.40 \\
Ash & 2.18 & 3.50 \\
\hline
\end{tabular}

The means and standard deviation of DMI, BCS, and BW during the 2-wk pretrial period, and milk yield and composition during the second week of the pretrial period are shown in Table 3.

\section{$D M I, B W$, and $B C S$}

There was a treatment by week interaction for DMI (Table 4; $P=0.09$ ). Cows fed FGC tended to have a greater DMI at wk 1 compared with cows fed EXC. However, at wk 2 cows fed FGC had a $1.3 \mathrm{~kg} / \mathrm{d}$ reduction in DMI, whereas cows fed EXC had an increase in DMI $(0.8 \mathrm{~kg} / \mathrm{d})$ relative to wk 1 . There were significant decreases in DMI at wk 4 and 6 for both groups due to increased environmental temperature and humidity that were observed for the entire herd during those periods (Figure 1). Dhiman et al. (2002) found no significant differences in DMI between cows fed a ration containing FGC and cows fed a ration containing highly processed, steam-flaked corn. In contrast, other studies (Shabi et al., 1999; Burkholder et al., 2004) have reported decreased feed intake when cows were fed highly processed corn (steam-flaked or extruded corn) compared with cows fed less-processed corn (ground corn). Shabi et al. (1999) concluded that the decreased DMI for cows fed extruded corn may have been related to the lower density of the extruded corn. In the present study, the densities and the particle size of the 2 corn grains were similar $(0.54 \mathrm{vs} .0 .58 \mathrm{~kg} / \mathrm{L}$, and $0.7 \mathrm{~mm}$, respectively) and that may have accounted for the lack of treatment effect on DMI.

Body weight and BCS did not differ by method of processing corn (Table 4). These observations are in agreement with Knowlton et al. (1998) and Dann et al. (1999), who also did not detect significant differences in BW or change in BW for cows fed rations containing corn processed by various methods.

\section{Milk Production and Composition}

As shown in Table 5, milk yield was influenced by the interaction of treatment, week, and parity $(P=0.03)$. 
Table 3. The mean and standard deviation (SD) of DMI, BCS, and BW during the pretrial (averaged over $2 \mathrm{wk}$ ) period, and milk yield and milk composition during the pretrial (1 wk) period for multiparous and primiparous cows fed rations containing either finely ground corn (FGC) or extruded corn (EXC)

\begin{tabular}{|c|c|c|c|c|c|c|c|c|}
\hline \multirow[b]{3}{*}{ Item } & \multicolumn{4}{|c|}{ FGC } & \multicolumn{4}{|c|}{ EXC } \\
\hline & \multicolumn{2}{|c|}{ Multiparous } & \multicolumn{2}{|c|}{ Primiparous } & \multicolumn{2}{|c|}{ Multiparous } & \multicolumn{2}{|c|}{ Primiparous } \\
\hline & Mean & $\mathrm{SD}$ & Mean & $\mathrm{SD}$ & Mean & $\mathrm{SD}$ & Mean & $\mathrm{SD}$ \\
\hline $\mathrm{n}$ & \multicolumn{2}{|c|}{8} & \multicolumn{2}{|c|}{3} & \multicolumn{2}{|c|}{8} & \multicolumn{2}{|c|}{4} \\
\hline 2-wk period & & & & & & & & \\
\hline $\mathrm{DMI}, \mathrm{kg} / \mathrm{d}$ & 21.2 & 1.47 & 19.4 & 0.53 & 20.3 & 2.82 & 18.5 & 1.41 \\
\hline $\mathrm{BCS}$ & 3.05 & 0.52 & 3.29 & 0.16 & 3.16 & 0.5 & 3.28 & 0.21 \\
\hline BW, kg & 699 & 60.0 & 545 & 40.6 & 659 & 36.2 & 545 & 24.7 \\
\hline \multicolumn{9}{|l|}{ 1-wk period } \\
\hline Milk yield, kg/d & 37.8 & 5.45 & 32.4 & 4.56 & 40.1 & 7.28 & 35.3 & 1.94 \\
\hline Milk protein, \% & 3.01 & 0.37 & 2.98 & 0.30 & 2.76 & 0.27 & 2.75 & 0.14 \\
\hline Milk fat, $\%$ & 3.15 & 0.48 & 3.36 & 0.37 & 2.95 & 0.57 & 3.26 & 0.39 \\
\hline Milk lactose, $\%$ & 4.63 & 0.26 & 5.04 & 0.26 & 4.32 & 0.31 & 4.78 & 0.12 \\
\hline
\end{tabular}

During wk 3 through 8, multiparous cows fed EXC produced more milk than multiparous cows fed FGC, with no treatment effect observed for primiparous cows, likely due to small sample size ( $\mathrm{n}=4$ and 3 , respectively; Figure 2). Dhiman et al. (2002) also reported that milk production was greater for multiparous cows fed steamflaked compared with finely ground corn. In contrast, Shabi et al. (1999) reported that cows fed ground corn rations produced $3 \%$ more milk than cows fed extruded corn rations. In the present study, a greater milk yield was observed only for the multiparous cows during wk 3 through 8 fed EXC compared with multiparous cows fed FGC. The lack of treatment effect for primiparous cows may be related to the small sample size. However, it is unknown why primiparous cows may differ from multiparous cows in response except that the energy requirement for growth would be greater for primiparous cows and limit available energy for milk production.

There was a treatment by parity interaction for milk fat percentage (Figure 3; SEM $=0.15 ; P=0.03$ ). Multiparous cows fed EXC produced milk with a reduced fat content compared with multiparous cows fed FGC (2.86 vs. $3.38 \%$, respectively), with no treatment effect observed for primiparous cows. Dhiman et al. (2002) reported that milk fat content was significantly less for cows fed a ration containing finely ground corn compared with that of coarsely ground corn. Reduction in milk fat may be related to a reduction in rumen $\mathrm{pH}$ and decrease in rumen production of acetic acid (Macleod et al., 1994; Overton et al., 1995; Arieli et al., 1996; Plascencia and Zinn, 1996). Shabi and coworkers (1999) reported that milk fat yield was reduced with no change in milk fat percentage and FCM for cows fed the extruded corn. This observation may have been related to lower milk yield for cows fed extruded corn and the shorter duration of the study (2-wk period per treatment) conducted by Shabi et al. (1999). In the present study, milk fat and FCM yields did not differ between the treatment groups during the $8 \mathrm{wk}$ of the experiment (Table 5). Theurer et al. (1999) summarized several studies that support these results, in that milk fat yield was not significantly influenced by corn processing method.

During wk 5 through 8, primiparous cows fed EXC produced milk with significantly greater protein con-

Table 4. The least squares means and standard error of the means (SEM $\left.{ }^{1}\right)$ of DMI, BCS, and BW for cows fed rations containing either finely ground corn (FGC) or extruded corn (EXC) during the study period (8 $\mathrm{wk})^{2}$

\begin{tabular}{|c|c|c|c|c|c|c|}
\hline \multirow[b]{2}{*}{ Item } & \multicolumn{2}{|c|}{ Ration } & \multirow[b]{2}{*}{ SEM } & \multicolumn{3}{|c|}{$P$-value ${ }^{3}$} \\
\hline & FGC & EXC & & $\mathrm{T}$ & $\mathrm{T} \times \mathrm{W}$ & $\mathrm{T} \times \mathrm{P} \times \mathrm{W}$ \\
\hline $\mathrm{N}$ & 11 & 12 & & & & \\
\hline DMI, $\mathrm{kg} / \mathrm{d}$ & 24.1 & 24.0 & 0.84 & 0.92 & 0.09 & 0.17 \\
\hline BCS & 3.22 & 3.24 & 0.09 & 0.85 & 0.86 & 0.54 \\
\hline $\mathrm{BW}, \mathrm{kg}$ & 661 & 637 & 18.7 & 0.36 & 0.45 & 0.49 \\
\hline
\end{tabular}

\footnotetext{
${ }^{1}$ Unequal $\mathrm{n}$, therefore largest SEM $(\mathrm{n}=11)$ reported.

${ }^{2}$ The effect of week was significant $(P<0.001)$ for DMI and BW.

${ }^{3} \mathrm{~T}=$ treatment effect; $\mathrm{T} \times \mathrm{W}=$ interaction between treatment effect and week $(\mathrm{W})$ effect; $\mathrm{T} \times \mathrm{P} \times \mathrm{W}=$ interactions among treatment effect, parity $(\mathrm{P})$ effect, and week effect.
} 


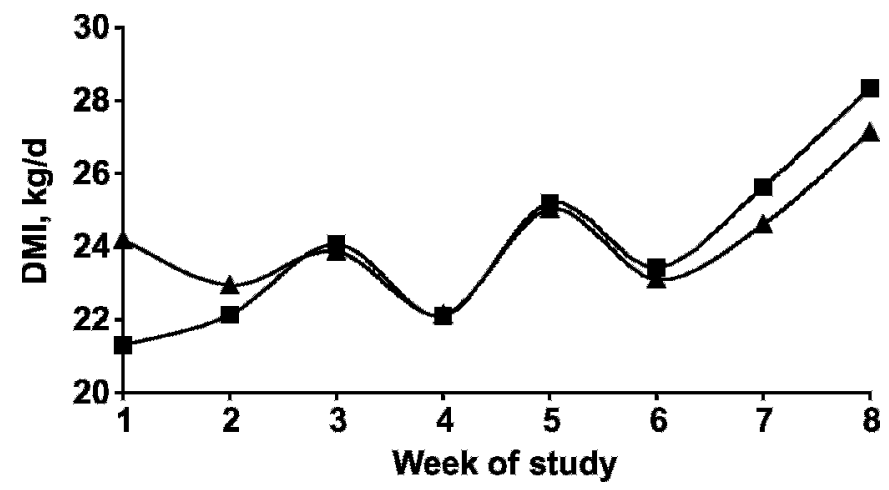

Figure 1. Dry matter intake $(\mathrm{kg} / \mathrm{d})$ of cows fed extruded corn (EXC; - - - ) or finely ground corn (FGC; - - ) during the 8-wk study period.

tent compared with primiparous cows fed FGC (Figure 4). The parity difference in treatment effect on milk protein content may have been due to a dilution effect of greater milk yield on milk protein content by multiparous cows fed extruded corn. Another possibility is that the ration protein did not meet the nutrient requirement for multiparous cows. However, based on evaluation of the rations using the Cornell-Penn-Miner Dairy model (version 3.0.7a; Cornell University, Ithaca, NY), MP (predicted) was supplied in excess of nutrient requirements for both primiparous and multiparous cows.

Increasing the rumen degradability of carbohydrates by grain processing may improve nitrogen utilization

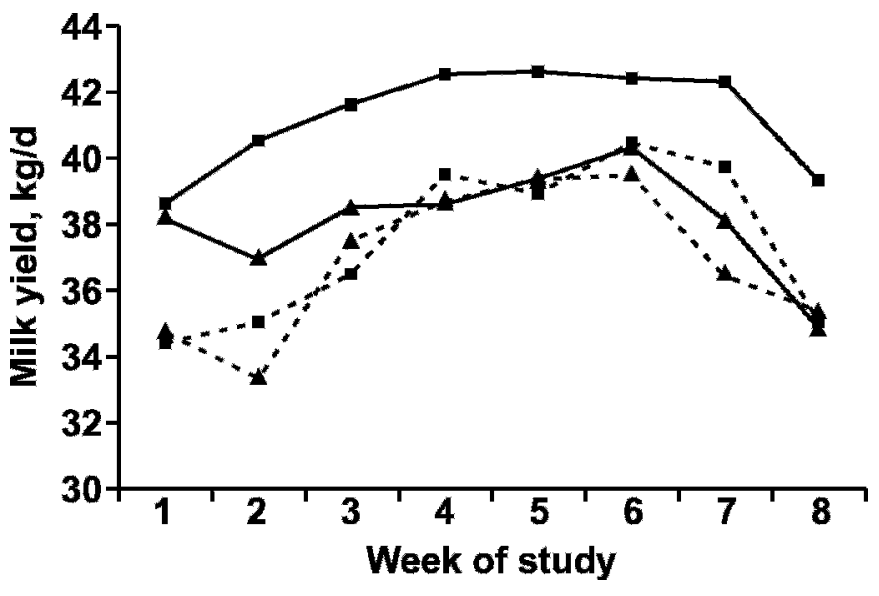

Figure 2. Milk yield (kg/d) of multiparous cows fed extruded corn (EXC; - - ) or finely ground corn ( $\mathrm{FGC} ;-\mathbf{\Delta}-)$ and primiparous cows fed EXC (------) or FGC (--- $\mathbf{-}---)$.

in the rumen. Zinn (1990) determined that, as the degree of processing of grains increased, there was an increase in microbial protein flow to the small intestine, thereby increasing the protein supply for the animal. It has been shown that feeding higher rumen-degradable NSC decreases the rumen $\mathrm{pH}$ and increases the rumen propionate concentration in dairy cows, which may result in a sparing of glucogenic amino acids (Overton et al., 1995; Arieli et al., 1996). This may partially explain an increase in milk yield for multiparous cows at wk 5 to 8 and milk protein content for primiparous cows in

Table 5. The least squares means and standard error of the means $\left(\mathrm{SEM}^{1}\right)$ of milk yield and compositions for cows fed rations containing either finely ground corn (FGC) or extruded corn (EXC) during the study period $(8 \mathrm{wk})^{2}$

\begin{tabular}{|c|c|c|c|c|c|c|}
\hline \multirow[b]{2}{*}{ Item } & \multicolumn{2}{|c|}{ Ration } & \multirow[b]{2}{*}{ SEM } & \multicolumn{3}{|c|}{$P$-value ${ }^{3}$} \\
\hline & FGC & EXC & & $\mathrm{T}$ & $\mathrm{T} \times \mathrm{W}$ & $\mathrm{T} \times \mathrm{P} \times \mathrm{W}$ \\
\hline $\mathrm{n}$ & 11 & 12 & & & & \\
\hline Milk yield, kg/d & 37.8 & 39.0 & 2.59 & 0.71 & 0.60 & 0.03 \\
\hline $\mathrm{FCM}, \mathrm{kg} / \mathrm{d}$ & 36.4 & 36.4 & 0.98 & 0.96 & 0.95 & 0.98 \\
\hline \multicolumn{7}{|l|}{ Fat } \\
\hline$\%$ & 3.33 & 3.06 & 0.09 & 0.02 & 0.34 & 0.91 \\
\hline $\mathrm{kg} / \mathrm{d}$ & 1.23 & 1.20 & 0.04 & 0.63 & 0.69 & 0.97 \\
\hline \multicolumn{7}{|l|}{ Protein } \\
\hline$\%$ & 2.98 & 3.12 & 0.06 & 0.09 & 0.30 & 0.01 \\
\hline $\mathrm{kg} / \mathrm{d}$ & 1.21 & 1.17 & 0.05 & 0.58 & 0.55 & 0.20 \\
\hline \multicolumn{7}{|l|}{ Lactose } \\
\hline$\%$ & 4.92 & 4.80 & 0.08 & 0.30 & 0.94 & 0.31 \\
\hline $\mathrm{kg} / \mathrm{d}$ & 1.85 & 1.88 & 0.13 & 0.91 & 0.90 & 0.07 \\
\hline MUN, ${ }^{4}$ mg/dL & 12.3 & 11.7 & 0.55 & 0.46 & 0.06 & 0.008 \\
\hline $\mathrm{SCS}^{5}$ & 1.62 & 1.67 & 0.51 & 0.94 & 0.42 & $<0.001$ \\
\hline
\end{tabular}

\footnotetext{
${ }^{1}$ Unequal $n$; largest SEM $(\mathrm{n}=11)$ reported

${ }^{2}$ The effect of week was significant for milk yield and all milk composition $(P<0.01)$.

${ }^{3} \mathrm{~T}=$ treatment effect; $\mathrm{T} \times \mathrm{W}=$ interaction between treatment effect and week $(\mathrm{W})$ effect; $\mathrm{T} \times \mathrm{P} \times \mathrm{W}=$ interactions among treatment effect, parity $(\mathrm{P})$ effect, and week effect

${ }^{4}$ MUN analysis of wk 4 of the study was excluded from the statistical analysis due to technical problems.

${ }^{5}$ Log transformation of SCC.
} 


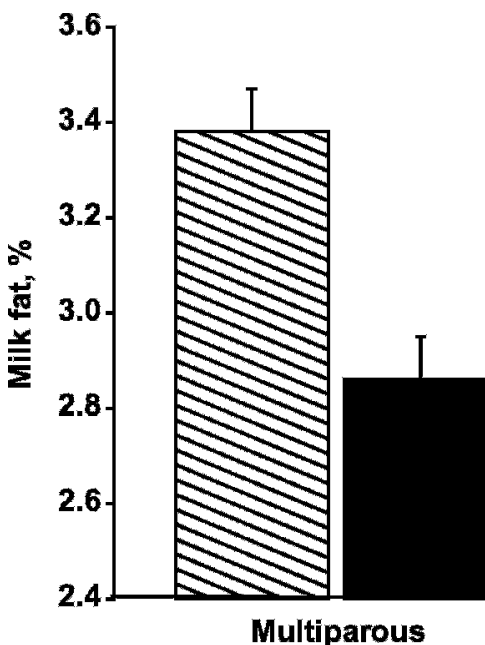

Multiparous

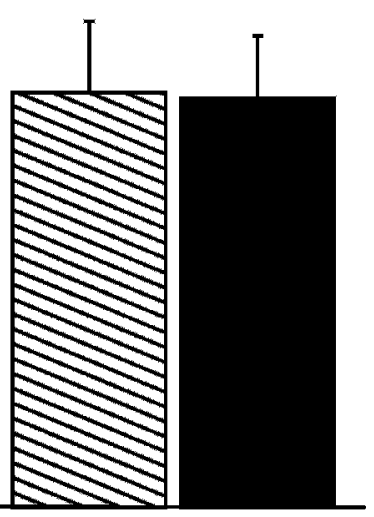

Primiparous

Figure 3. Milk fat percentage of multiparous and primiparous cows fed finely ground corn (hatched bars; FGC) or fed extruded corn (solid bars; EXC). $P=0.03$ for the interaction of treatment by parity.

the EXC group. In contrast, Theurer et al. (1999) found no change in microbial protein flows with increased grain processing. Shabi et al. (1999) observed that the efficiency of milk protein synthesis (milk protein/CP intake) increased when cows were fed extruded corn compared with cows fed ground corn. In the present study, the efficiency of milk protein synthesis (data not shown) did not differ between the 2 experimental groups ( 0.31 for both treatment groups) and milk protein yields were not affected by treatment (Table 5 ). However, results should be interpreted with caution due to the low number of primiparous cows in each experimental group ( $\mathrm{n}=4$ and 3 for cows fed EXC and FGC, respectively).

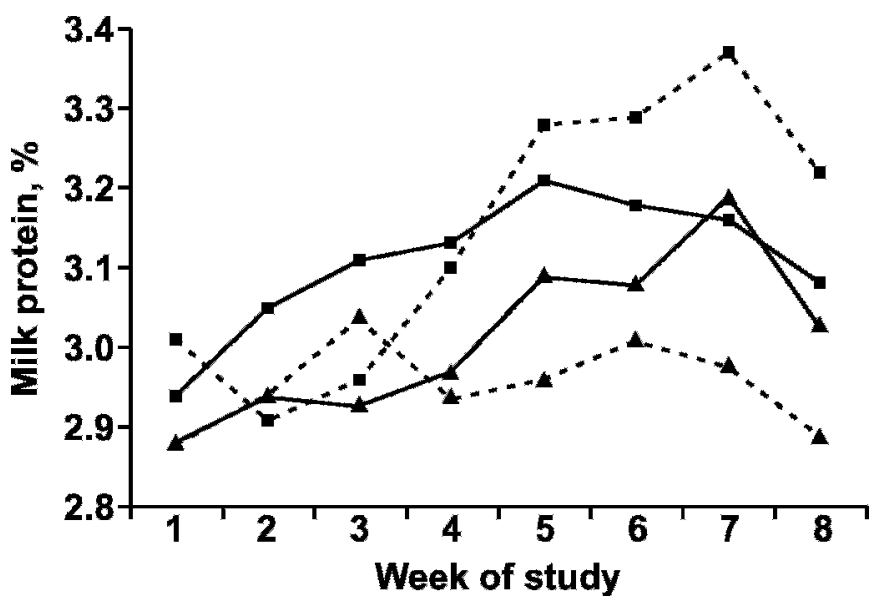

Figure 4. Milk protein percentage of multiparous cows fed extruded corn (EXC; - - - ) or finely ground corn (FGC; $-\mathbf{\Delta -}$ ) and

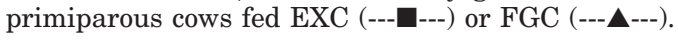

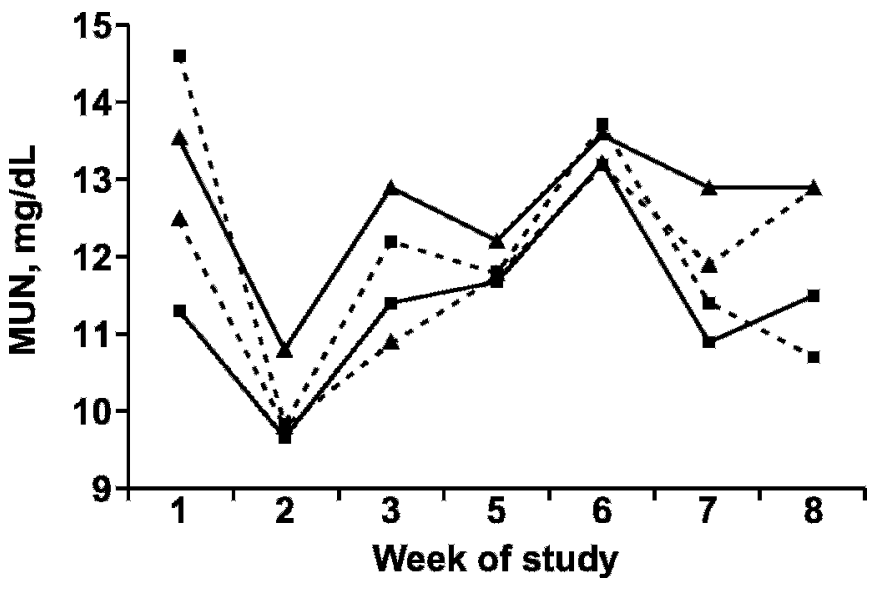

Figure 5. Milk urea $\mathrm{N}(\mathrm{mg} / \mathrm{dL})$ of multiparous cows fed extruded corn (EXC; - - - ) or finely ground corn (FGC; - $\mathbf{-}-$ ) and primiparous cows fed EXC (------) or FGC (--- - --). Analysis of MUN for wk 4 was excluded from the study due to analytical errors.

No significant differences were detected in lactose percentage and yield (Table 5). This observation is in agreement with Dhiman et al. (2002) and Knowlton et al. (1998). Although there was a significant interaction of treatment, parity, and week in SCC linear score $(P$ $<0.001$ ), the data were variable and there were no significant differences detected within parity or within week due to dietary treatment in the present study.

Due to technical problems, the analysis of MUN at wk 4 of the study was excluded from the statistical analysis. Multiparous cows fed FGC had significantly greater MUN concentrations compared with multiparous cows fed EXC during wk 7 of the study, with no treatment effect observed for primiparous cows $(P=$ 0.04; Figure 5). Burkholder et al. (2004) reported that MUN content was reduced for cows fed steam-flaked corn compared with cows fed dry ground corn, and concluded that this observation was due to an increase in $\mathrm{N}$ utilization for milk protein synthesis in cows fed highly processed corn. Milk urea N concentrations were highly variable by week in the present study; therefore, a conclusion of the effect of extruded corn on MUN concentration is equivocal.

\section{CONCLUSIONS}

In this experiment, multiparous cows fed EXC produced more milk during wk 3 to 8 with reduced milk fat percentage compared with cows fed FGC. In contrast, primiparous cows fed EXC produced milk with a greater protein percentage during wk 5 to 8 than did primiparous cows fed FGC. Dry matter intake, BCS, and BW were not affected by treatment. With regard to the milk protein content, the results should be interpreted with 
caution because of the low number of primiparous cows in each experimental group. Inclusion of $2.70 \mathrm{~kg} / \mathrm{d}$ of extruded corn in the ration during mid lactation increased milk yield for multiparous Holstein cows and reduced milk fat content.

\section{ACKNOWLEDGMENTS}

This research was partially supported by Blue Seal Feed Inc. (Londonderry, NH). The authors would like to thank David Schreiber Jr., Kevin Kouri, and Kasey Moyes for assistance in feeding and sample collection. Appreciation is extended to Arnold Nieminen, manager of the Kellogg Dairy Center at the University of Connecticut, for animal care.

\section{REFERENCES}

Arieli, A., Z. Shabi, I. Bruckental, H. Tagari, Y. Ahorani, S. Zamwell, and H. Voet. 1996. Effect of the degradation of organic matter and crude protein on ruminal fermentation in dairy cows. J. Dairy Sci. 79:1774-1780.

Burkholder, K. M., A. D. Guyton, J. M. McKinney, and K. F. Knowlton. 2004. The effect of steam flaked or dry ground corn and supplemental phytic acid on nitrogen partitioning in lactating cows and ammonia emission from manure. J. Dairy Sci. 87:2546-2553.

Castells, M., S. Marin, V. Sanches, and A. J. Ramos. 2005. Fate of mycotoxins in cereals during extrusion cooking: A review. Food Addit. Contam. 22:150-157.

Chen, K. H., J. T. Huber, B. Theurer, R. S. Swingle, J. Simas, S. C. Chan, Z. Wu, and J. L. Sullivan. 1994. Effects of steam flaking of corn and sorghum grains on performance of lactating cows. J. Dairy Sci. 77:1038-1043.

Crocker, L. M., E. J. DePeters, J. G. Fadel, H. Perez-Monti, S. J. Taylor, J. A. Wyckoff, and R. A. Zinn. 1998. Influence of processed corn grain in diets of dairy cows on digestion of nutrients and milk composition. J. Dairy Sci. 81:2394-2407.

Dann, H. M., G. A. Varga, and D. E. Putnam. 1999. Improving energy supply to late gestation and early postpartum dairy cows. J. Dairy Sci. 82:1765-1778.

Dhiman, T. R., M. S. Zaman, I. S. MacQueen, and R. L. Boman. 2002. Influence of corn processing and frequency of feeding on cow performance. J. Dairy Sci. 85:217-226.

Goff, J. P. 2006. Major advances in our understanding of nutritional influences on bovine health. J. Dairy Sci. 89:1292-1301.

Knowlton, K. F., M. S. Allen, and P. S. Erickson. 1996. Lasalocid and particle size of corn grain for dairy cows in early lactation. 1. Effect on performance, serum metabolites, and nutrient digestibility. J. Dairy Sci. 79:557-564.

Knowlton, K. F., B. P. Glenn, and R. A. Erdman. 1998. Performance, ruminal fermentation, and site of starch digestion in early lacta- tion cows fed corn grain harvested and processed differently. J. Dairy Sci. 81:1972-1984.

Kotarski, S. F., R. D. Waniska, and K. K. Thurn. 1992. Starch hydrolysis by the rumen microflora. J. Nutr. 122:178-190.

Macleod, G. K., P. E. Colucci, A. D. Moore, D. G. Grieve, and N. Lewis. 1994. The effect of feeding frequency concentrates and feeding sequence of hay on eating behavior, ruminal environment and milk production in dairy cows. Can. J. Anim. Sci. 74:103-113.

NRC. 1989. Nutrient Requirements of Dairy Cattle. 6th rev. ed. Natl. Acad. Sci., Washington, DC.

Overton, T. R., M. R. Cameron, J. P. Elliot, J. H. Clark, and D. R. Nelson. 1995. Ruminal fermentation and passage of nutrients to the duodenum of lactating cows fed mixture of corn and barley. J. Dairy Sci. 78:1981-1998.

Owens, N. F., R. A. Zinn, and Y. K. Kim. 1986. Limits to starch digestion in the ruminant small intestine. J. Dairy Sci. 63:1634-1648.

Plascencia, A., and R. A. Zinn. 1996. Influence of flake density on the feeding value of steam-processed corn in diets for lactating cows. J. Anim. Sci. 74:310-316.

Remond, D., J. I. Caberera-Estrada, M. Champion, B. Chauveau, R. Coudrue, and C. Poncet. 2004. Effect of corn particle size on site and extent of starch digestion in lactating cows. J. Dairy Sci. 87:1389-1399.

Roe, M. B., and C. J. Sniffen. 1990. Techniques of measuring protein fractions in feedstuffs. Pages 81-85 in Proc. Cornell Nutr. Conf. Feed Manf., Rochester, NY. Cornell Univ., Ithaca, NY.

Ryu, D., M. A. Hanna, and L. B. Bullerman. 1999. Stability of zearalenone during extrusion of corn grits. J. Food Prot. 62:1482-1484.

SAS Institute. 1999. SAS User's Guide Statistics. Version 8 ed. SAS Institute Inc., Cary, NC.

Shabi, Z., I. Bruckental, S. Zamwell, H. Tagari, and A. Arieli. 1999. Effects of extrusion of grain and feeding frequency on rumen fermentation, nutrient digestibility, and milk yield and composition in dairy cows. J. Dairy Sci. 82:1252-1260.

Theurer, C. B. 1986. Grain processing effects on starch utilization by ruminants. J. Anim. Sci. 63:1649-1662.

Theurer, C. B., J. T. Huber, A. Delgado-Elorduy, and R. Wanderley. 1999. Invited review: Summary of steam-flaking corn or sorghum grain for lactating dairy cows. J. Dairy Sci. 82:1950-1959.

Theurer, C. B., O. Lozano, A. Alio, A. Delgado-Elorduy, M. Sadik, J. T. Huber, and R. A. Zinn. 1999. Steam-processed corn and sorghum grain flaked at different densities alter ruminal, small intestinal, and total tract digestibility of starch by steers. J. Anim. Sci. 77:2824-2831.

Van Soest, P. J., and D. G. Fox. 1992. Discounts for net energy and protein. 5th Rev. Pages 40-69 in Proc. Cornell Nutr. Conf. Cornell Univ., Ithaca, NY.

Wildman, E. E., G. M. Jones, P. E. Wagner, H. F. Troutt, and T. N. Lesch. 1982. A dairy cow body condition scoring system and its relationship to selected production characteristics milk production. J. Dairy Sci. 65:495-501.

Zinn, R. A. 1990. Influence of flake density on the comparative feeding value of steam-faked corn for feedlot cattle. J. Anim. Sci. 68:767-775. 